\title{
DESEMPREGO TECNOLÓGICO NA INDÚSTRIA: UMA ANÁLISE SOBRE O SETOR TÊXTIL NO BRASIL
}

\author{
Guilherme Barbosa de Oliveira*
}

Resumo: O progresso técnico é estudado desde os primeiros economistas. As discussões sobre o tema afirmam que essa variável é de suma importância para o crescimento econômico, entretanto o trabalho humano empregado na produção é reduzido. Partindo dessa constatação, o objetivo desta pesquisa é analisar as implicações do progresso técnico no desemprego do setor têxtil brasileiro. É uma pesquisa bibliográfica, descritiva e analítica. Conclui-se que o setor têxtil brasileiro possui desemprego tecnológico, onde progresso técnico gerou aumentos na produção, todavia, desempregou trabalhadores com menos qualificação profissional.

Palavras-chave: Desemprego Tecnológico; Progresso Técnico; Setor Têxtil.

\begin{abstract}
Technical progress has been studied since the first economists. Discussions on the subject state that this variable is extremely important for economic growth, but the human labor used in production is reduced. Based on this, the objective of this research is to analyze the implications of technical progress on unemployment in the Brazilian textile sector. It is
\end{abstract}

\footnotetext{
* Mestrando em Economia Aplicada no Programa de Pós-Graduação em Economia Aplicada da Universidade Federal de Ouro Preto - UFOP. E-mail: guilhermeboliveira13@ gmail.com. O presente trabalho foi realizado com apoio da Fundação de Amparo à Pesquisa de Minas Gerais (FAPEMIG).
} 
a bibliographic, descriptive and analytical research. It is concluded that the Brazilian textile sector is going through the process of technological unemployment, where technical progress has generated significant increases in production, however, it has dismissed workers with little professional qualification.

Keywords: Technological unemployment; Technical Progress; Textile sector.

JEL: B24; E24

\section{Introdução}

Em decorrência das técnicas e ferramentas que foram se aprimorando ou inventadas desde o início da humanidade até os dias atuais, a sociedade passou e passa por transformações no modo e no padrão de consumo, produção e convivência. Essas técnicas e ferramentas, mesmo que rudimentares, são nomeadas de tecnologias, sendo o processo de aprimoramento dessas tecnologias, denominada como progresso técnico.

Sendo estudada desde os primeiros economistas, a tecnologia, o progresso técnico ou processo de inovação tecnológica, eram tratados endogenamente aos modelos econômicos assumindo um grande papel para o crescimento. Passou a ser tratada como variável exógena a partir de 1960, sendo atualmente (2021), uma das principais variáveis para o crescimento econômico sustentado.

Os debates sobre a relação entre inovação tecnológica/progresso técnico e emprego dizem que essa variável consegue trazer ganhos significativos de produtividade, aumentando a competitividade da empresa. Em contrapartida, o trabalho humano diretamente envolvido na produção torna-se cada vez, menos necessário. Essa redução do trabalho humano envolvido na produção, em função do progresso técnico é denominado como desemprego tecnológico. 
Um dos principais exemplos da ocorrência do desemprego tecnológico, pode ser observado no setor têxtil das economias desenvolvidas. Indústria antes intensiva em mão-de-obra, em 2019 já possui etapas da cadeia de produção totalmente autônomas ou que exigem menos trabalhadores para o seu funcionamento (CNI, 2017).

No caso brasileiro, o país já possui indústrias têxteis quase que $100 \%$ autônomas, exceto pelo acionamento (Portal da Indústria, 2018). Empresas cujo o pedido da peça de roupa entra por uma solicitação dentro de um sistema de software, logo no início do processo produtivo e em cerca alguns minutos depois a peça é produzida e finalizada.

Esses investimentos no setor em fábricas autônomas são recentes e estão sendo aplicados principalmente em São Paulo e no Rio de Janeiro (CNI, 2017). Portanto, não pode ser considerado uma realidade para toda a nação, cujo o nível de desigualdade, tanto econômica quanto técnico-industrial, é facilmente observável.

Uma vez que o desemprego tecnológico é uma realidade mundial, quais são as principais caraterísticas desse processo? Já é uma realidade no Brasil? Existe meios de minimizar as implicações negativas do progresso técnico na economia no que tange aos trabalhadores?

O presente artigo se propõe a responder essas perguntas a partir de uma análise para o Brasil buscando apresentar as possíveis implicações do progresso técnico (inovação em maquinaria) na economia, a partir de um estudo teórico-empírico sobre o setor têxtil brasileiro.

Para esta análise, este trabalho pretende discutir as principais teorias sobre a inovação tecnológica enquanto um processo de desenvolvimento capitalista e, ao mesmo tempo, como gerador de desemprego; realizar uma busca histórica do setor têxtil no Brasil, buscando apresentar a história do setor no território nacional e as principais mudanças que o progresso técnico gerou em sua cadeia produtiva; e analisar dados sobre a indústria têxtil e os trabalhadores empregados nele, buscando verificar as implicações da inovação tecnológica no desemprego no setor. 


\section{Progresso Técnico e a Inovação Tecnológica na Teoria Econômica}

Desde Adam Smith (1776) em seu livro, "A riqueza as nações: Investigações sobre as suas naturezas e causas", já atribuía grande importância as máquinas e equipamentos, afirmando que as mesmas "abreviam" e "facilitam" o trabalho humano ao otimizar a produção em todos os níveis. Segundo o autor, a criação das máquinas veio como consequência da divisão do trabalho, onde a repartição dos processos de produção, antes realizados apenas por uma pessoa, passa a ser desempenhado por vários trabalhadores. Esse método de rateamento dos processos produtivos faz com que a atenção do trabalhador seja dirigida para uma função, mudando o foco de sua mente e ocupando-a em meios de aprimorar a execução daquela atividade, afim de facilitar e otimizar aquele determinado processo no qual ele está empenhado.

Deste modo, com os trabalhadores focados em aumentar a sua produtividade individual, buscam meios de aprimorarem os métodos e mecanismos de produção com novas ferramentas, técnicas e máquinas. Com a produtividade individual potencializada pelo progresso técnico, os capitalistas começam a demandar mais máquinas e ferramentas, originando uma nova profissão, a de fabricação de máquinas. Tão importante era o progresso tecnológico para o crescimento da produção, que criaram novas profissões para o desenvolvimento de máquinas, ferramentas e técnicas.

Essas novas máquinas e melhorias seriam aplicadas na cadeia produtiva em que os operários estão inseridos, visando o crescimento da renda nacional. Conforme a produção e a renda crescia, novos investimentos seriam realizados demandando mais trabalhadores.

Assim, naquele contexto da $1^{\circ}$ Revolução Industrial, o desemprego seria reduzido conforme ocorre o aumento da produção e dos investimentos, não existindo desemprego tecnológico para Adam Smith.

Contrapondo essa visão de que as máquinas elevam a demanda por trabalho, Ricardo escreve em seu livro sobre o desemprego gerado pela introdução da maquinaria. Ele estava "convencido de que a substituição 
de trabalho humano por maquinaria é frequentemente (...) prejudicial aos interesses da classe dos trabalhadores" (RICARDO (1817), 1996, p.288).

Nas duas primeiras edições do seu livro, "Princípios de economia política e tributação", Ricardo diz que, se há incremento de máquinas, ocorre o "melhoramento dos meios de fabricação, mesmo quando o número de trabalhadores envolvidos no processo produtivo se mantém inalterado", havendo "ganhos de produtividade" mesmo se for por um curto período de tempo (RICARDO (1817), 1996, p.26). A princípio, ele afirmava que a introdução das máquinas oferece benefícios aos capitalistas e trabalhadores, uma vez que os preços reduziam e os salários nominais permaneciam constantes, haveria um aumento de lucros e dos salários reais. Os trabalhadores que perderam o emprego em função dessa introdução da maquinaria poderiam encontrar trabalho em outra indústria necessária à sociedade.

Após algumas discussões com Bardon e McCulloch no século XIX, Ricardo muda a sua opinião sobre o incremento de máquinas no processo produtivo, afirmando que a "substituição de trabalho humano por maquinaria é frequentemente muito prejudicial aos interesses da classe dos trabalhadores" (RICARDO (1817), 1996, p.288).

Segundo o autor, existe dois tipos de capital a serem investidos pelas empresas capitalistas. O capital fixo (máquinas e equipamentos) e o capital circulante (salários). O incremento de capital fixo faz com que a produção se mantenha ou aumente, reduzindo ao longo do tempo os investimentos em capital circulante. Conforme ocorre esse movimento, os custos seriam reduzidos e a produção líquida aumentaria. Assim, a introdução das máquinas "pode aumentar o rendimento líquido do país" e ao mesmo tempo, tornar a oferta de trabalho excedente "e deteriorar as condições de vida dos trabalhadores” (RICARDO (1817), 1996, p.288).

Já Karl Marx (1867), no livro "O capital, crítica da Economia Política [Livro I]: O processo de produção do capital”, faz uma crítica ao capitalismo e a economia política. Em seu trabalho, ele afirma que a maquinaria - descrita por Ricardo - pode sim aumentar o desemprego, mas isso dependerá da velocidade com o que ocorrem os avanços tecnológicos, do crescimento demográfico, dos novos investimentos e se ocorrerá ou não uma redução da jornada de trabalho. 
Segundo Marx (1867), na manufatura o homem usava as ferramentas, mas com a criação das máquinas, as ferramentas passam a ser apenas um mecanismo, um instrumento que possibilita melhoria da produção. A força motriz para utilizar as ferramentas varia conforme o tamanho e a quantidade de processos que ela realiza e como "homem é um instrumento muito imperfeito para a produção de um movimento contínuo e uniforme", ele é passível de substituição (MARX (1867), 2013, p.306).

Essa ideia pode ser exemplificada. Supondo um grupo de cinco pessoas, onde cada indivíduo executa uma função, todos irão especializar-se nessa determinada função e assim aumentar a produtividade individual. A matéria prima vai passar por cada pessoa envolvida até se tornar um bem final. Marx diz que os movimentos repetitivos dos trabalhadores são imperfeitos e que eles não conseguem realizá-los continuamente ao longo do tempo. Já uma máquina, conseguiria fazer todos os processos perfeitamente e com um custo de desgaste relativamente baixo e uma velocidade maior. Portanto, o homem é passivel de ser substituído por elas no processo produtivo.

Como um capitalista sempre busca a maximização dos lucros, ele irá substituir "o trabalhador que maneja uma única ferramenta por um mecanismo que opera com uma massa de ferramentas iguais ou semelhantes de uma só vez e é movido por uma única força motriz" (MARX (1867), 2013, p.305). Se em uma manufatura o isolamento dos processos é um princípio dado pela divisão de trabalho apresentada anteriormente pelo Adam Smith em 1776, "na fábrica desenvolvida predomina, ao contrário, a continuidade dos processos particulares" por meio das máquinas (MARX (1867), 2013, p.308).

Levando em consideração o crescimento demográfico, o desemprego será causado não só pela substituição do homem pela máquina, mas também pelo aumento populacional, expandindo o que Marx chama de "exército industrial de reserva". Esse exército industrial de reserva é composto pelos indivíduos que querem trabalhar, mas não encontram emprego e pelos não podem, em função de doenças, condicionamento físico, idade, etc., e por aqueles que não querem trabalhar. 
Na visão marxista, os novos investimentos podem criar novos postos de trabalhos, uma vez que significa mais industrias e empresas. Mas, essa criação só seria capaz de tornar a demanda por trabalho maior que a oferta, se esses investimentos ocorressem com maior velocidade que o progresso técnico e do crescimento demográfico. Caso contrário, a grande oferta continuará pressionando os salários para baixo, reduzindo a qualidade de vida dos trabalhadores.

Schumpeter em seus livros "Capitalismo, Socialismo e Democracia" (1942) e "Teoria do desenvolvimento econômico: Uma investigação sobre os lucros, capital, crédito, juro e o ciclo econômico" (1911), contrapõe e crítica em partes a teoria de Karl Marx no que tange o desemprego, progresso técnico e as suas consequências, principalmente livro de 1911.

Para Schumpeter, o progresso técnico não possui uma relação direta com o desemprego. O aumento ou queda dos trabalhadores empregados é função dos períodos de ascensão ou crise econômica. O fator determinante desse crescimento econômico não seria a acumulação de capital ou a automação dos processos produtivos, como aparece nas teorias clássicas, marxistas e neoclássicas, mas sim por causa das inovações (SCHUMPETER (1942), 1961).

Ele busca explicar como a criação de novos processos produtivos, por meio das inovações tecnológicas da produção, influenciam no crescimento econômico. Segundo o autor, a inovação tecnológica promove transformações que podem afetar toda economia, e a longo prazo, consegue reduzir os preços de alguns (não todos) os produtos. Essas transformações na economia, sejam nos modos de produção, novos bens, serviços e mercados, são resultados do desenvolvimento capitalista. Ele afirma que ao longo do tempo, os processos produtivos, ferramentas, bens e serviços, passam por uma "transformação qualitativa", onde o caráter evolutivo do sistema capitalista deve-se ao aumento da população e do capital. Ambas as transformações são criadas pela empresa capitalista, inclusive as novas organizações industriais - novos modos de produção, incluindo novas técnicas, máquinas etc. (SCHUMPETER (1911), 1997, cap.7).

Conforme for havendo inovações, alguns métodos, postos de trabalhos, estruturas, bens e serviços desaparecerão. Porém, será criado novos 
bens e serviços, novas empresas, novos postos de trabalhos, etc. É o que ele chama de "destruição criadora".

Com a criação de novos processos produtivos ganhando importância, "o progresso tecnológico se transforma cada vez mais em atividade de grupos de especialistas, que fornecem o que se lhes encomenda e fazem o produto operar de uma maneira previsível", culminando na criação de novos empregos nesse ramo de especialização (SCHUMPETER (1942), 1961, p.167).

Schumpeter considera as inovações tecnológicas como uma das variáveis necessárias para o desenvolvimento econômico. Para o autor, o desenvolvimento engloba uma combinação de cinco etapas, dentre elas i) a criação de um novo bem, ii) a criação de um novo método de produção - e aqui pode ser uma nova máquina ou nova técnica, ou seja, alguma inovação tecnológica do processo produtivo -, iii) abertura de novo mercado, iv) novos fornecedores e v) uma reorganização da indústria (SCHUMPETER (1911), 1997, p.76). Cabe ao empresário realizar as combinações dos meios de produção, buscando criar novas formas de produção, novos bens de consumo e novos mercados. Deste modo, obtém-se não só o crescimento econômico, como também o desenvolvimento.

\subsection{As revoluções industriais e o aprimoramento tecnológico}

Ao longo da história, constatam-se vestígios de instrumentos, métodos e técnicas, que vão desde ferramentas rudimentares até as mais avançadas máquinas para a realização de tarefas essenciais, necessárias à sobrevivência do ser humano. De acordo Dalmaso e Coutinho (2010), a criação de ferramentas, técnicas e processos dos meios de execução das atividades e do trabalho humano, são tecnologias, sendo classificadas com maior ou menor nível tecnológico, conforme o contexto histórico no qual estão inseridas.

Com o surgimento de novas contribuições tecnológicas, esses instrumentos, métodos de outrora foram incorporados ao conhecimento cientifico em diversas áreas da pesquisa, o que propiciou a sua expansão e desenvolvimento, substituindo e extinguindo muitas dessas ferramentas e técnicas, seja por aprimoramento das mesmas ou pela criação de novas. Esses 
aprimoramentos e invenções de novas máquinas e equipamentos para a realização das tarefas humanas, será denominada inovação tecnológica. Deste modo, qualquer invenção ou melhoria de uma técnica, máquina ou ferramenta que facilite ou aumente a produção, conforto, saúde, etc. será caraterizado como inovação tecnológica.

A propagação de novas tecnologias possui uma relação positiva com o nível do crescimento econômico. Partindo da teoria schumpeteriana dos ciclos econômicos ${ }^{1}$, para relacionar as variáveis, explicando que os "booms" econômicos surgem quando as inovações tanto de máquinas, ferramentas e técnicas quanto de novos produtos e serviços, surgem (CONCEIÇÃO; FARIA, 2003). Deste modo, pode-se citar os principais períodos históricos que houve o maior número de invenções e aprimoramentos tecnológicos, uma vez que esses períodos são acompanhados por um forte crescimento da produção como por exemplo, as três revoluções industriais.

Em 1760, quando se iniciou a primeira grande Revolução Industrial, o padrão tecnológico muda repentinamente e os processos produtivos evoluem de forma extraordinária, transformando o modo de vida e as relações interpessoais daquele período, dando origem ao Sistema Capitalista. De acordo Cavalcante e Silva (2011), esse momento caracterizou-se, principalmente, pelo rápido crescimento demográfico, forte êxodo rural e avanço do desenvolvimento científico. O excesso de mão-de-obra barata, mercado consumidor crescente, aliado a expansão das invenções na área tecnológico-fabril, proporcionou a acumulação de capital dos capitalistas que chefiavam as fábricas no período. Segundo os autores, essa combinação das "invenções na indústria têxtil, das máquinas a vapor, na indústria de mineração, dos transportes ferroviários e marítimos", promoveram a I Revolução Industrial, mecanizando os processos de produção (CAVALCANTE; SILVA, 2011, p.3).

\footnotetext{
${ }^{1}$ Segundo Schumpeter (1911), o sistema econômico "não anda sempre para frente", sem tropeços. Existem incidentes dos mais variáveis tipos, colapsos que travam - momentaneamente - o caminho do desenvolvimento. Esses períodos de ascensão e queda do crescimento é denominado por Schumpeter de "Ciclos Econômicos". Sempre que uma técnica, ferramenta, produto, serviço, máquina, etc., for inovador, garantindo ao seu proprietário um lucro extraordinário - lucratividade acima do lucro econômico de mercado, - ocorrerá uma ascensão da produção e geração de empregos e aumento de salários. Quando essa tecnologia for acessivel, haverá a entrada de novos correntes reduzindo a lucratividade e o interesse do investimento, ocorrendo queda dos postos de trabalho e dos salários, resultando na queda do crescimento.
} 
Assim, o progresso técnico acelerado no século XVIII foi desenvolvido com a finalidade de, por um lado, facilitar as atividades humanas da sociedade e por outro lado, objetivava de otimizar a produção por meio da redução de custos. Esse movimento progressivo de mecanização dos processos produtivos, desqualificava o trabalho humano, precarizando ainda mais as condições de trabalho e de remuneração, que acaba por gerar paradas da produção, por meio de greves e revoltas contra as máquinas e as fábricas ao longo do tempo (CAVALCANTE; SILVA, 2011). A sociedade demonizava a tecnologia, culpando-as pelas altas taxas de desemprego e baixo nível salarial.

Outro período histórico que teve grande influência tecnológica nas mudanças dos padrões de produção e convivência, ocorreu a partir de 1850, período da II Revolução Industrial.

Os grandes marcos da II Revolução Industrial, iniciada por volta de 1850-1870 e terminando em meados 1945 , podem ser evidenciados a partir dos desenvolvimentos ocorridos nas indústrias química, comunicação, petróleo, criação do aço, entre outras (DATHEIN, 2003).

De acordo Dathein (2003), a criação do aço assumiu papel fundamental na indústria, uma vez que houve a invenção do conversor Bressemer, houve o desenvolvimento da fornalha tipo Siemens-Martin, dentre outras máquinas e ferramentas, que aumentavam drasticamente a produção, reduzindo o custo por unidade produzida levando a uma intensa substituição do ferro pelo aço em áreas de suma importância, como a do transporte ferrovias e construção naval - e nos armamentos. Além de melhorar as condições de produção, tais invenções auxiliam e facilitam a vida da sociedade, uma vez que vários utensílios domésticos são feitos a partir do aço.

Ainda segundo o autor, a criação da eletricidade foi outro grande marco da II Revolução Industrial. Além de proporcionar aumentos exponenciais na produção, 
seu baixo custo. Facilitou também o desenvolvimento de pequenas indústrias, que podiam agora utilizar a mesma fonte geradora de energia das grandes e pagar de acordo com o seu consumo. As descobertas no âmbito da eletricidade atravessaram o século XIX (DATHEIN, 2003, p.6).

As novas fontes de energia - energia elétrica e o petróleo -, os novos materiais e os novos processos tecnológicos, propiciaram uma transformaram rápida dos métodos produtivos, se mecanizando e se tornando cada vez mais autônomos, permitindo cada vez mais a redução dos custos de produção, gerando externalidades, positivas como a ampliação do número de produtos disponiveis para consumo, e negativas para a sociedade como um todo, como o surgimento de oligopólios, aumento da poluição, etc. Novamente a tecnologia moldando a indústria e modificando a sociedade, pelo seu consumo, nas relações sociais de trabalho, etc. (DATHEIN, 2003).

Em 1914, a produção passa a ser padronizada com o surgimento do Fordismo, onde o progresso técnico ocorreu em "termos de organização da produção no chão de fábrica", modificando o estilo de produção dos trabalhadores (RIBEIRO, 2015, p.68). Com a criação e implementação da esteira rolante, houve uma "intensificação, automatização e mecanização do processo de trabalho", onde o modo com o qual os trabalhadores exerciam as suas atividades foram fortemente controlados, havendo muitos ganhos de produtividade (RIBEIRO, 2015, p.69).

Com o desenvolvimento dessa nova organização do trabalho, modificando e aprimorando o ramo administrativo, o fordismo também pode ser caraterizado como progresso técnico, uma vez que envolve o aprimoramento/invenção de uma ou mais técnicas de produção afim de otimizá-la.

A partir de 1950, com desenvolvimento das comunicações eletrônicas e dos sistemas de computadores, alguns processos passam ser realizados em segundos a um custo significativamente baixo (FREEMAN; SOETE, 2008). Alguns pesquisadores como Jacob Gorender, Soraya Maria de Medeiros e Semíramis Melani Melo Rocha, classificam esse período como a Terceira Revolução Industrial. 
Essas transformações na cadeia de produção, reforçaram a essência capitalista da maximização constante dos lucros e da acumulação de capital, principalmente com o processo de globalização que nasce entre 1970 em 1990, fenômeno este, semelhante ao processo de internacionalização (GORENDER, 1997), uma vez que a globalização nasceu junto com a terceira revolução industrial, tendo como objetivo, o barateamento do processo produtivo por meio da internacionalização de tecnologias, máquinas, equipamentos e conhecimento, "enquanto a internacionalização tem como foco o relacionamento entre as nações" a partir da mobilidade dos seres humanos (BACKES, et al., 2014, p.1).

Além de expandir exponencialmente o mercado mundial, a globalização intensificou as relações internacionais por meio das mídias, telecomunicações e transportes, possibilitando mais investimentos e a entradas de capitais, tanto fisicos quanto financeiros entre os paises, transformando os processos de produção não apenas dos países desenvolvidos, anteriormente denominados de países de primeiro mundo, mas de todas as nações que fosse de interesse do capitalista (BACKES, 2014).

Embora essa transferência de capitais entre as nações seja uma variável importante na superação de crises econômicas do sistema capitalista, com as crescentes inovações tecnológicas, mecanização e automação dos processos produtivos, esses movimentos de capitais ganham um novo objetivo. Uma sobretaxa de lucros em relação aos concorrentes (MEDEIROS; ROCHA, 2004). Sempre que uma nova tecnologia - criação ou aprimoramento de uma nova técnica - surgir, a empresa irá patenteá-la garantindo pra si essa sobretaxa de lucro. Essas inovações, tanto em produtos quanto nos meios de produção, gera um aumento de receita na firma em questão, fazendo com que ela obtenha uma taxa de lucro acima da taxa de lucro normal do mercado. Entretanto, com o passar do tempo, essa sobretaxa irá desaparecer na medida em que essa mesma tecnologia é consumida ou utilizada pelos concorrentes, "gerando uma pressão permanente na busca de novas tecnologias e descobertas científicas que possibilitem inovações tecnológicas para a obtenção da sobretaxa de lucros" (MEDEIROS; ROCHA, 2004, p.407). Essa constante busca pela maximização do lucro, leva à crescente automação do processo produtivo dos diversos setores econômicos, obrigando-os a elevar os investimentos dedicados ao aprimoramento e de- 
senvolvimento de novas máquinas, para garantir-lhes vantagens em relação as concorrentes (MEDEIROS, ROCHA, 2004).

A partir 1990, com a globalização, as empresas então passaram a intensificar os investimentos em P\&D (Pesquisa e Desenvolvimento) objetivando o desenvolvimento de mecanismos minimizadores de custos ou que lhes proporcionem vantagens nas vendas. Freeman e Soete (2008), quando discute sobre a criação e destruição de empregos em função das inovações tecnológicas, constata que o desemprego, ou "fora do emprego", é duas vezes maior entre os trabalhadores com menos educação do que com os trabalhadores mais qualificados (FREEMAN; SOETE, 2008).

Assim, a automação e as inovações tecnológicas cria novos postos de trabalhos com uma demanda por trabalhadores mais qualificados e técnicos levando a uma redução do número de empregados na linha de produção, enquanto o número de pessoas empregadas na geração, distribuição e processamento do conhecimento e da inovação continua aumentando (FREEMAN; SOETE, 2008).

A partir do referencial acima acerca da importância e das implicações que progresso técnico tem na economia e na sociedade, pode-se restringir a análise das implicações do progresso técnico no desemprego ao setor têxtil. O setor foi o pioneiro da $1^{a}$ Revolução Industrial, portanto, o próximo tópico tem por objetivo, discorrer sobre a indústria têxtil no Brasil. Será apresentado o seu histórico, o seu desenvolvimento tecnoindustrial e as transformações recentes que sofreu, exibindo as mudanças que sofreu em função do progresso técnico.

\section{A História do Setor Têxtil no Brasil}

Ao mencionar o histórico do setor têxtil brasileiro é indispensável destacar o papel da tecnologia nas fases da sua evolução e as mudanças percebidas no setor que influenciaram seu processo de desenvolvimento.

A indústria têxtil aparece como uma das pioneiras no processo de mecanização da produção (MAIA et al, 2006). No Brasil Colônia, já se percebia 
a atividade econômica têxtil com o grande plantio de algodão no norte e nordeste do país, além de diversas manufaturas têxteis, sendo considerada de subsistência até o fim do século XIX (NEIRA, 2013).

Conforme Fujita e Jorente (2015), essa estrutura produtiva manufatureira do Brasil Colônia evoluía de maneira lenta. Isso porque "a industrialização não era de interesse dos portugueses, que controlavam totalmente o mercado brasileiro", interrompendo assim, o processo de desenvolvimento industrial em 1785 (p.158).

Até a primeira metade do século XVIII, não havia grandes tecnologias e máquinas empregadas na produção no mundo, o processo era artesanal e manufatureiro. Foi na segunda metade do século XVIII, com o advento da Primeira Revolução Industrial que a produção evolui tecnologicamente, havendo uma concentração técnica - técnicas, máquinas e equipamentos - na Inglaterra (POCHMANN, 2016). Com a criação da máquina a vapor por Thomas Newcomen, e o seu aperfeiçoamento James Watt, a indústria têxtil foi a primeira a utilizar a nova tecnologia aplicando essas tecnologias em máquinas como a Mula Giratória ${ }^{2}$, Jenny de fiação ${ }^{3}$ e o Shuttle Voador ${ }^{4}$ (SAKURAI; ZUCHI, 2018).

No Brasil, com a vinda da família real em 1808, o governo português revogou o alvará que interrompia a industrialização do setor e abriu o mercado (FUJITA; JORENTE, 2015). Associado com o boom britânico na produção de tecidos e de desenvolvimento de máquinas e equipamentos que modernizava a cadeia produtiva, a demanda mundial por algodão aumentou, resultando na maior produção da commodity e na absorção de algumas tecnologias que ajudaram na retomada da industrialização no setor, ainda que de maneira lenta.

\footnotetext{
${ }^{2}$ É uma máquina usada para girar algodão e outras fibras, usada principalmente no final do século XVIII ao início do século XX. Foi inventado entre 1775 e 1779 por Samuel Crompton (BAYNES, 1835).

${ }^{3} \hat{E}$ um quadro de fiação multi-fuso, sendo considerado uma das principais invenções criadas dentro da industrialização da tecelagem durante o início da Revolução Industrial. Foi inventado em 1764 por James Hargreaves na Inglaterra. O item reduziu a quantidade de trabalho humano necessária para produzir o fio, com o trabalhador passando a produzir oito ou mais carretéis de uma única vez (BAYNES, 1835).

${ }^{4}$ Outra das principais invenções desenvolvidas na industrialização da tecelagem durante o início da Revolução Industrial, esse instrumento permitiu que um trabalhador tecesse tecidos mais largos, existindo a possibilidade ser mecanizado, permitindo teares automáticos para máquinas. Foi patenteado por John Kay em 1733 (BAYNES, 1835).
} 
Mesmo com o aumento da demanda de algodão, a Inglaterra conseguiu reduzir drasticamente os custos de produção, inibindo a concorrência internacional. Associado a isso, o plano econômico adotado pelo Brasil, entre 1808 e 1843, que barateava as tarifas alfandegarias em relação aos produtos ingleses, contribuindo para o desenvolvimento lento da indústria têxtil no país (MARINGONI, 2012).

Em 1866, o Brasil tinha 42 fábricas têxteis registradas, com capacidade instalada de 66.466 fusos, conseguindo produzir vinte milhões de metros de tecidos (MAIA, et al, 2006). Grande parte dessas fábricas se encontravam instaladas na Bahia, "pois dispunha de uma grande população escrava, matéria prima em abundância e fontes hidráulicas de energia" (FUJITA; JORENTE, 2015, p.160). Já em 1882, o Brasil tinha 48 fábricas têxteis produzindo 20 milhões de metros de tecido anualmente. Foram criadas apenas 6 fábricas após 16 anos.

Nos anos subsequentes, houve um aumento mais expressivo desse número, onde foram criadas 86 novas fábricas do setor, totalizando 134 fábricas, situadas em 17 estados do país (COSTA; BERMAN; HABIB $2000^{5}$ e STEIN, $1979^{6}$ apud FUJITA; JORENTE, 2015, p.9).

As tarifas sobre as importações que foram adotadas no início da Proclamação da República, concederam altos lucratividade ao setor, atraindo investimentos. Isso porque os proprietários das fábricas não calculavam os seus preços de acordo os custos de produção, mas sim pelos custos de importação, que no período, estavam inflados pelas tarifas aduaneiras. Isso garantia preços altos (menores que os produtos têxteis estrangeiros) e altos lucros (EMERY, 2007).

Outro fator que pode ter implicado nesse aumento, foi o aquecimento do mercado mundial. Pochmann (2016) identifica uma redução da participação inglesa da produção industrial mundial a partir de 1880 até 1928 - e com previsão de queda até 2040, - enquanto a participação estadunidense entrava em ascensão. Após 1953, os Estados Unidos também entrariam

\footnotetext{
${ }^{5}$ COSTA, Shirley; BERMAN, Debora; HABIB, Roseane Luz. 150 anos da indústria têxtil brasileira. Rio de Janeiro: SenaiCetiqt/Texto\&Arte, 2000.

${ }^{6}$ STEIN, Stanley J. Origens e evolução da indústria têxtil no Brasil - 1850/1950. Rio de Janeiro: Editora Campus LTDA, 1979
} 
em queda e a China tomaria espaço no mercado internacional após 1980. Deste modo, torna-se atrativo para a indústria brasileira produzir para o exterior, principalmente após 1950, quando inicia o processo de queda do poder de mercado norte-americano.

Com a maior produtora têxtil perdendo espaço industrial dentro da produção mundial, torna-se interessante produzir para exportar, principalmente para os países vizinhos como Argentina, Chile, Equador, cujo o nível de industrialização se encontrava bem abaixo do brasileiro.

Diante desse contexto, o setor têxtil e de vestuário, um dos setores industriais melhores disseminadas no mundo, vem sendo marcado pelo desenvolvimento em infraestrutura produtiva, que se transformou em parques industriais, composto por uma cadeia produtiva que abarca toda uma rede de infra segmentos, como beneficiamento, fiação, tecelagem, acabamento e confecções. Essa indústria constitui "uma importante fonte de geração de renda e emprego para muitos países, especialmente aqueles em fase de desenvolvimento" (MAIA et al, 2006, p.11). Assim, o desenvolvimento de parques industriais produtivos se fez necessário para atender a demanda de larga escala no mercado interno e externo (FUJITA; JORENTE, 2015, p.155).

A Crise Econômica de 1929 nos Estados Unidos implicou diretamente no setor. A queda no preço dos produtos agrícolas reduziu a renda da população brasileira, retraindo a demanda por produtos têxteis. A partir de 1930, o governo iniciou a Política de Substituições de Importações, dando a devida importância para a indústria reduzindo o poder dos cafeicultores sobre as tomadas de decisões das políticas públicas a serem praticadas. Uma das medidas que favoreçam os proprietários das fábricas do setor, foram as restrições de importação de máquinas cujo o governo considerava a produção excessiva de 1931 até 1938. Deste modo, o estado dificultou a competitividade no setor, garantindo mais lucratividade para indústria têxtil (EMERY, 2007).

Na década de 1940, com as grandes potências mundiais envolvidas na Segunda Guerra Mundial, o Brasil encontrou uma grande oportunidade. Os países com maior poder econômico estagnaram parte de sua pro- 
dução, desaparecendo do mercado mundial. Mas a felicidade durou pouco, quando em 1945 com o fim da guerra, os países voltaram a produzir em escala maior e preços extremamente competitivos, retirando rapidamente o posto brasileiro do mercado mundial (EMERY, 2007).

Segundo MAIA et al (2006) o setor têxtil brasileiro não se desenvolveu tanto em termos tecnoindustriais até 1950/60. Estudo da Cepal mostra que nesse período devido a obsolescência técnica o setor têxtil sofreu uma recessão. Ademais problemas organizacionais também afetaram o setor. Buscando alternativas para estruturar o setor, a indústria investiu em qualificação da mão de obra e direcionou para o mercado da moda (TEIXEIRA, $2007^{7}$ apud FUJITA; JORENTE, 2015).

Com a proposta desenvolvimentista do Plano de Metas do Juscelino Kubitscheck, maior interação entre os mercados internacionais a indústria voltou a evoluir, principalmente com a introdução da eletrônica. Com a ascensão da indústria da moda na década de 1960, o setor começou a investir em feiras, máquinas e mão-de-obra capacitada, afim de encontrar as tendências de roupas e tecidos, direcionando a sua produção (FUJITA; JORENTE, 2015).

No início da década de 1970, o governo havia concedido incentivos fiscais para a importação de máquinas e equipamentos, buscando trazer tecnologia estrangeira, mas a Crise do Petróleo em 1973 impactou negativamente nesse processo. O governo buscou evitar a perda exacerbada de divisas, passando a retirar as isenções fiscais da indústria, reduzindo os investimentos subsequentes (EMERY, 2007).

Em 1980, "o setor têxtil estava fragilizado e tecnologicamente atrasado em comparação aos Estados Unidos, Europa e agora a Ásia” (FUJITA; JORENTE, 2015, p.164). Em função do modelo protecionista embasado no projeto de substituição de importações, a indústria têxtil ainda se mostrava atrasado tecnologicamente, "enquanto as importações de fios e tecidos sintéticos e artificiais" cresciam. As exportações ainda apresentavam estabilidade, gerando conflitos entre elos da cadeia produtiva (FUJITA; JORENTE, 2015).

7 TEIXEIRA, Francisco MP. A história da indústria têxtil paulista. Sinditêxtil-SP, 2007. 
Ainda na década de 1980, o governo brasileiro começou a racionalizar a sua estrutura tarifária. Em 1990, liberalizou de vez as transações financeiras e eliminou as barreiras contra a importação abrindo o mercado brasileiro. A abertura comercial aliada a estabilização da inflação e paridade real/dólar feito pelo Plano Real em 1994, aumentou o consumo elevando o nível de investimentos, o que resultou na maior relação entre capital e trabalho (KON; COAN, 2005).

Algumas etapas da cadeia têxtil foram prejudicadas, como a produção de tecidos planos, "resultando na falência de muitas empresas, especialmente produtoras de tecidos artificiais e sintéticos, mais atingidos pelas importações da Ásia" (KON; COAN, 2005, p.18). No entanto, mesmo com o impacto negativo para algumas empresas do setor, a produção de malhas, que cresceu $29,7 \%$, o que representou um crescimento médio de $2,96 \%$ ao ano durante 1990 a 1999 . Os demais ramos da cadeia produtiva têxtil tiveram um crescimento relativamente baixo, como a produção de fios que cresceu apenas $0,6 \%$ ao ano e a produção de tecidos que cresceu $0,5 \%$ ao ano durante o período (KON; COAN, 2005).

Houve uma crescente importação de produtos têxteis da China, que em 2015, estava como "líder mundial em exportações de produtos têxteis e confeccionados" (FUJITA; JORENTE, 2015, p.166). Isso se deve não só por fatores externos como o fim do Acordo de Têxteis e Vestuário da OMC ou a crise econômica de 2008, que fragilizou ao Estados Unidos e alguns países europeus como a Inglaterra, principalmente. Mas, também por fatores internos ao país, como o trabalho intensivo e com baixos salários, a variedade de produção e a capacidade de produzir a própria matéria prima para quase todos os tipos de tecidos (FUJITA; JORENTE, 2015).

Conforme observado, o setor têxtil do Brasil possui baixa tecnologia em sua cadeia produtiva, sendo uma "tecnologia básica dos processos produtivos" que "está incorporada nos equipamentos" (MAIA et al, 2006, p.29). Desde o Brasil Colônia, teve pouco incentivo ao investimento, sendo na Primeira República e após a entrada do Getúlio Vargas no poder, que setor que recebeu mais apoio estatal. Sem grandes inovações em território nacional, a cadeia têxtil sofreu fortes pressões em períodos de ascensão internacionais, principalmente com a globalização em 1980/1990. 
Seu grande destaque produtivo encontra-se na malharia, onde consegue produzir malhas em grandes quantidades a custos relativamente baixos, sendo competitivos em dentro e fora das fronteiras. A empregabilidade encontra-se ameaçada com a difusão e implementação da indústria 4.0. Essa quarta revolução industrial e tecnológica demanda mão de obra com alta capacitação técnica para os novos postos de trabalhos que serão criados na cadeia produtiva e tende a automatizar as etapas de produção que exigem trabalho manual, extinguindo um grande número de postos de trabalhos.

\subsection{As transformações recentes}

As transformações recentes ocorridas no setor têxtil brasileiro e a estrutura produtiva da indústria têxtil vem sendo marcada nos últimos anos por novos padrões tecnológicos de produção e de concorrência. A empresas do setor buscam reduzir cada vez mais os custos a fim de se tornarem competitivas no mercado internacional, mantendo a qualidade e atendendo os novos desejos dos consumidores.

Segundo a Confederação Nacional da Indústria (2017), em 2017, o setor busca instalar esse upgrade com base nas grandes ênfases temáticas estabelecidas por Flávio Silveira Bruno em seu livro "A Quarta Revolução Industrial do Setor Têxtil e de Confecção: a Visão de Futuro para 2030", sendo estas: A confecção, design, novas fibras e novos canais. O foco no desenvolvimento de novas tecnologias, tanto nos produtos quanto na cadeia produtiva, esteve presente desde o início da Revolução Industrial, e atualmente está na vanguarda da implementação da chamada Indústria 4.08.

\footnotetext{
${ }^{8}$ Sakurai e Zuchi (2018) sustenta a ideia de Kagermann et al. (2013), quando ao termo Indústria 4.0. Segundo os autores, essa denominação surgiu na Alemanha em 2011. Tinham por objetivo, "desenvolver uma abordagem para fortalecer a competitividade da indústria manufatureira alemã" (SAKURAI; ZUCHI, 2018). O novo modelo industrial proposto sustenta-se no desenvolvimento de novas formas produtiva com base na tendência da digitalização e automação do ambiente de manufatura (OESTERREICH; TEUTEBERG, 2016 apud SAKURAI; ZUCHI, 2018). De acordo Silveira (2017) a Indústria 4.0 busca conectar as máquinas, os sistemas e os ativos, onde as empresas poderiam criar redes inteligentes para controlar as diferentes etapas de produção de forma autônoma. Sakurai e Zuchi ainda define a Indústria 4.0, com base na visão de Zawadzki e Zywicki (2006), como o modelo de indústria que une as "conquistas tecnológicas dos últimos anos com a visão de um futuro com sistemas de produção inteligentes e automatizados, no qual o mundo real é ligado a virtual" (SAKURAI; ZUCHI 2018, p.485).
} 
A Confederação Nacional da Indústria (2017) prevê que haverá um aumento por produtos mais diversificados e tecnológicos, resultando no crescimento exponencial "da diversidade e a intensidade tecnológica de fios, tecidos, aviamentos e produtos auxiliares exigidos para atender a novas necessidades de consumo" (p.96). Para atender essas novas demandas, a indústria deve transformar o processo de produção, otimizando cada vez mais os custos produtivos tornando os produtos mais sustentáveis, socialmente justos, "agregando valores ao planeta e à sociedade". Deste modo, ele torna tanto o produto como o modo com o qual ele é produzido (os processos da cadeia de produção) mais aceito pela demanda.

Mesmo com maior produtividade, redução de custos, e consequentemente preços mais baixos, novos empregos, produtos inteligentes, etc., características que garantiria a recepção positiva pelos demandantes do setor, a indústria 4.0 encontra um desafio, principalmente quando tange atividades que historicamente são manuais e intensivas em mão-de-obra humana, como a cadeia têxtil. Como o surgimento de novas tecnologias automatiza os processos nas empresas, existe uma quebra de paradigma sobre perfil do profissional sempre que há uma revolução industrial ou o desenvolvimento de uma tecnologia de grande impacto, como por exemplo, a internet. Deste modo, "uma série de empregos deixará de existir com a implementação da indústria 4.0, devido à redução da quantidade de trabalhadores necessários na indústria" (MOESTER, $2017^{9}$ apud LAURITINO; LAURITINO; BOEMO, 2018, p.8).

Segundo Lauritino, Lauritino e Boemo (2018), com a expansão da indústria 4.0, a possibilidade de uso intensivo de alta tecnologia nas indústrias como as "fábricas inteligentes, aplicativos de produção eletrônica e interação entre sistemas inteligentes" provocará mudanças na "vida industrial, social e econômica da população" (p.11).

Deve-se considerar que a indústria 4.0 demanda mão-de-obra muito qualificada e que no Brasil, atualmente, a falta de qualificação desejada para a implementação dessa quarta revolução industrial é algo a ser destacadas (LAURITINO; LAURITINO; BOEMO, 2018.)

\footnotetext{
${ }^{9}$ MOESTER, D. Securing the future for the Manufacturing Industry: Towards the adoption of the Smart Industry. Universidade de Twente, 2017.
} 
Mesmo com a força de trabalho sem a qualificação esperada, a indústria 4.0 já é uma realidade no Brasil, contudo ela ainda é inexpressiva, especialmente se comparada com a realidade de outros países como Alemanha, Estados Unidos e Japão.

Conforme a Confederação Nacional da Industria (2017), já existe experimentos da aplicação de tecnologias e conceitos da indústria 4.0 no Brasil. Em 2015, Agência Brasileira de Desenvolvimento Industrial (ABDI), começou a criar uma planta produtiva baseada na Indústria 4.0 denominada 'Confecção do Futuro'. Primeiro foi realizado um diagnóstico dos processos da empresa, depois um projeto de viabilidade econômica para saber se é viável ou não da continuidade no projeto. Dentre as modernizações, "estão o investimento na produção em célula e sob demanda, customização em massa, tecnologia embarcada, integração mercadológica, conexão em redes e atuação global” (CNI, 2017, p.72).

De acordo a CNI (2017), em 2017 foi inaugurado pela Escola Senai Francisco Matarazzo em São Paulo e pelo Centro de Tecnologia da Indústria Química e Têxtil do Senai (Senai-Cetiqt) no Rio de Janeiro, duas mini fábricas totalmente autônomas, exceto pelo se acionamento. A planta do Rio de Janeiro confecciona calças legging, enquanto a de São Paulo confeccionará camisetas. "Assim como a Confecção do Futuro, servirão de modelo para empresas e demais instituições que as quiserem replicar" (CNI, 2017, p.73).

Com essa automação crescente da cadeia produtiva, a tendência é a redução, ainda mais dos postos de trabalhos que demandam profissionais menos qualificados. No setor têxtil então, cuja a produção é historicamente intensiva de mão-de-obra e um tanto quanto menos exigente no que se refere ao grau de escolaridade, a tendência é que conforme for ocorrendo essas instalações de máquinas e equipamentos com alto nível tecnológico, menor será a quantidade demandada de mão-de-obra.

\section{Tecnologia e Empregabilidade no Setor Têxtil Brasileiro}

É sabido que a tecnologia influencia diretamente a produtividade das indústrias. Para tanto, é importante descrever, mesmo que suscintamente, 
o estado da arte do desenvolvimento tecnológico do setor têxtil e suas relações e implicações para o emprego têxtil no Brasil.

Desde a década de 1990, com a abertura do mercado, que trouxe impactos diretos para a indústria, o setor têxtil sentiu a necessidade de se tornar mais competitivo, para tanto, o investimento em melhorias tecnológicas de seu maquinário ao longo da sua cadeia produtiva era fundamental, como também investimento tecnológico relativos aos novos processos de produção. De suma importância é a interligação da cadeia produtiva, com aquisição de melhorias tecnológicas em cada segmento ao longo da cadeia produtiva têxtil, para que cada etapa possa acompanhar e absorver o produto do segmento anterior, conferindo continuidade e competitividade da cadeia.

\section{Gráfico 1 - Receitas liquidas com vendas do setor têxtil (2008-2018)}

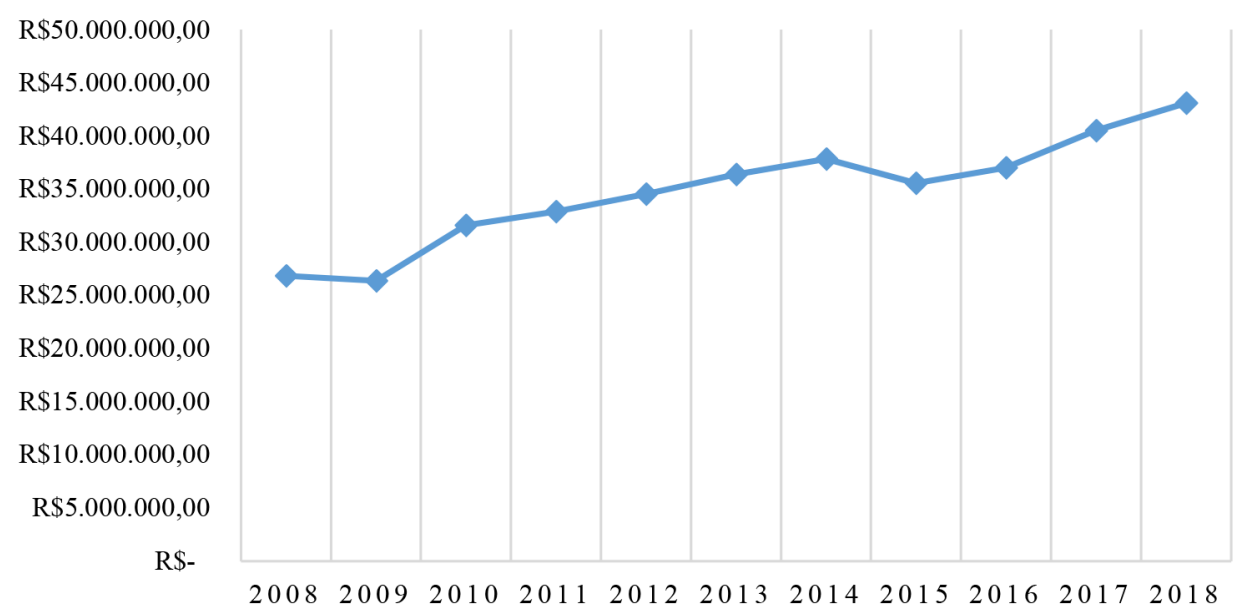

Fonte: Elaborado pelo autor. Dados obtidos na IBGE - Pesquisa Industrial Anual. Acesso em: 20 nov. 2019.

O gráfico 1 mostra os ganhos em receitas do setor. Isso expõe o quão produtivo o setor tem sido na última década. Mesmo com a Crise Subprime de 2008, em que alguns setores da economia com a construção civil e o setor automobilístico sofreram uma queda dos investimentos e do crédito ${ }^{10}$, o setor têxtil continuou a apresentar aumento em suas receitas, uma vez que se recuperou no ano seguinte com uma das maiores variações do período.

10 SANTOS, U. F; ALVES, T. G.: O papel do estado brasileiro na crise do subprime: Uma abordagem pós-keynesiana. Trabalho de Conclusão de Curso (Graduação em Relações Internacionais) - Universidade Federal de Uberlândia, Uberlândia, 2018. 
Isso se deve ao fato de que os dados do setor incluem o ramo de confecção de roupas, peças de cama e banho, etc., que em quantidade de estabelecimentos de médio e pequeno porte, é um número relativamente grande se comparado ao número de fábricas de tecidos e malhas.

Os dados apresentados no gráfico 2, exibem o desempenho no setor têxtil em relação à indústria nacional como um todo.

\section{Gráfico 2 - Participação do setor têxtil em relação ao valor bruto da produção industrial do Brasil (2008-2018)}

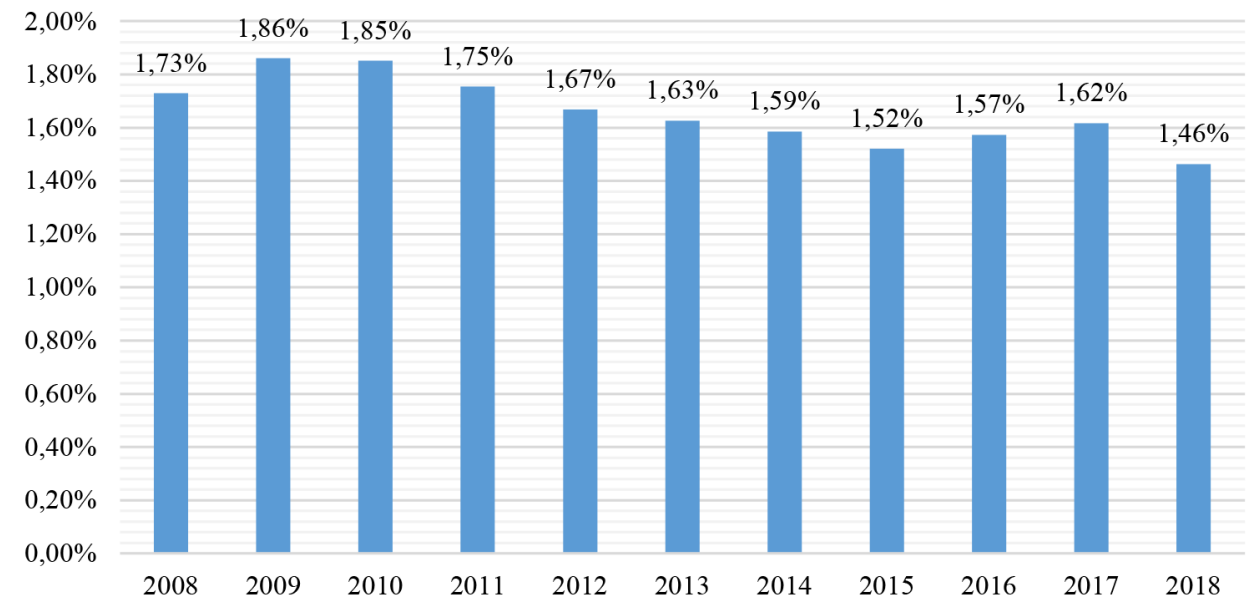

Fonte: Elaborado pelo autor. Dados obtidos na IBGE - Pesquisa Industrial Anual. Acesso em: 20 nov. 2019.

Nota-se um movimento ondular cada vez menor do setor. Essa queda da participação não quer dizer queda da produção especificamente. Um dos fatores explicativos para essa queda da participação seria pelo fato de que a indústria têxtil ter como principal ramo a confecção, sendo a maioria dos empreendimentos do setor, classificados como micro e pequenos empresas. Segundo a CNI (2017), isso dificulta os ganhos de "escala, eficiência, comunicação e convergência de ações em nível setorial, mas também oportunidades de melhoria e expansão, incluindo o investimento em exportações" (CNI, 2017, p.91).

Deste modo, o ramo vem perdendo participação da produção industrial do Brasil em nível de indústria, mas vem ganhando força em termos no comércio e na confecção. 


\section{Gráfico 3 - Variação anual dos valores brutos da produção industrial do setor têx- til e da produção industrial do Brasil (2002-2018)}

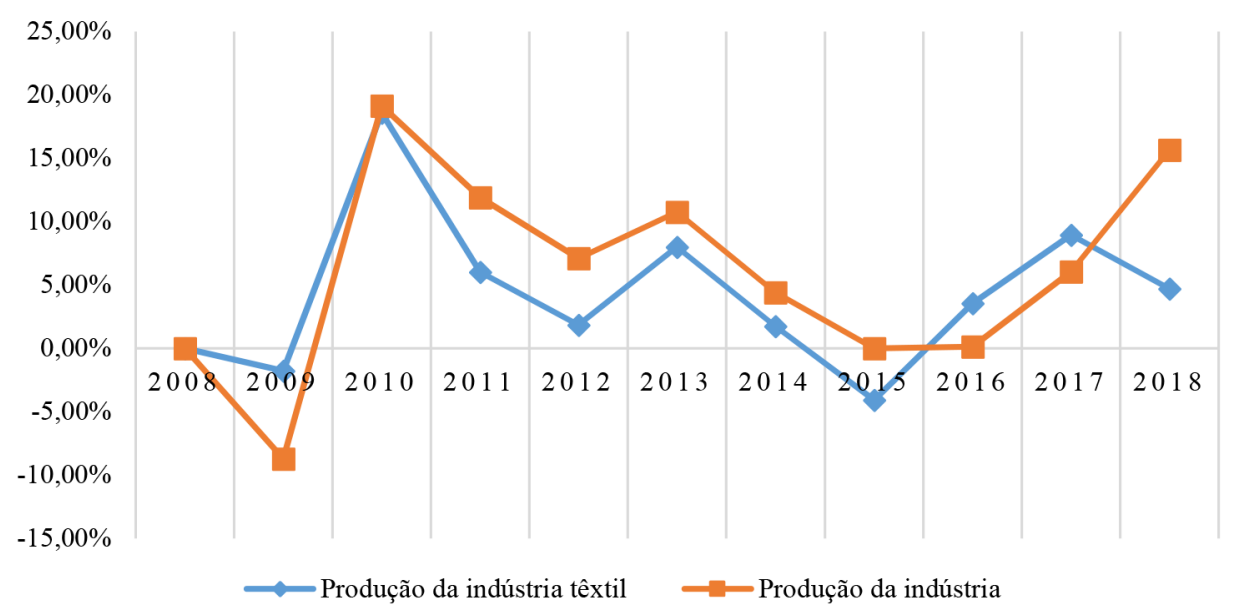

Fonte: Elaborado pelo autor. Dados obtidos na IBGE - Pesquisa Industrial Anual. Acesso em: 20/ nov. 2019.

Nota-se no gráfico 3 uma movimentação parecida e paralela entre as duas curvas, mostrando que em períodos de ascensão da indústria o setor têxtil também cresce, mesmo que com uma variação menor que a indústria geral. Em períodos de recessão, o setor também sofre com o decréscimo da indústria geral, como é o caso dos anos de 2009 e de 2011 a 2015.

Analisando o gráfico 2, juntamente com as informações apresentadas no gráfico 3 , apontam que a indústria em geral cresceu a uma velocidade maior do que a indústria têxtil. Segundo os dados, a produção industrial geral/total cresceu em média $6,04 \%$ ao ano, enquanto a produção da indústria têxtil cresceu em média $4,32 \%$.

Segundo os dados da CAGED, o número de estabelecimentos das indústrias metalúrgicas e mecânicas veio crescendo rapidamente, ou seja, outros segmentos industriais continuaram expandindo fortemente elevando o crescimento industrial geral, enquanto a indústria têxtil crescia mais timidamente. 
Tabela 1 - Variação das Indústrias Têxtil, Mecânica, de Calçados, Metalúrgica e Química nos anos de 1998, 2008 e 2017

\begin{tabular}{l|l|c|c|c}
\hline \multicolumn{2}{c|}{ IBGE Subsetor } & $\mathbf{1 9 9 8}$ & $\mathbf{2 0 0 8}$ & $\mathbf{2 0 1 7}$ \\
\hline \multirow{2}{*}{ Indústria Metalúrgica } & Número de estabelecimentos & 26.143 & 37.902 & 46.543 \\
& Variação & - & $44,98 \%$ & $22,80 \%$ \\
\hline \multirow{2}{*}{ Indústria Mecânica } & Número de estabelecimentos & 8.546 & 17.671 & 28.175 \\
& Variação & - & $106,78 \%$ & $59,44 \%$ \\
\hline \multirow{2}{*}{ Indústria Química } & Número de estabelecimentos & 17.614 & 24.160 & 25.302 \\
& Variação & - & $37,16 \%$ & $4,73 \%$ \\
\hline \multirow{2}{*}{ Indústria Têxtil } & Número de estabelecimentos & 41.350 & 60.735 & 60.093 \\
& Variação & - & $46,88 \%$ & $-1,06 \%$ \\
\hline \multirow{2}{*}{ Indüstria Calçados } & Número de estabelecimentos & 6.036 & 10.116 & 8.164 \\
& Variação & - & $67,59 \%$ & $-19,30 \%$ \\
\hline Total & & 99.689 & 150.586 & 168.278 \\
\hline
\end{tabular}

Fonte: Dados obtidos na RAIS/CAGED. Acesso em: 09 jan. 2020.

Como observado no gráfico 3, a produção industrial do setor variando menos que produção industrial total do Brasil dentro do intervalo de 2008 a 2018. É importante ressaltar que mesmo com o crescimento da receita do setor têxtil, como visto no gráfico 1, a participação da produção têxtil em relação a produção industrial total reduzia, saindo de 1,86\% em 2009 atingindo 1,46\% em 2018. Ou seja, ele cresceu bastante, mas não na mesma velocidade que outros setores.

No periodo de 1998 a 2018, houve um aumento exponencial de algumas industrias, como a metalurgia, a mecânica e a química, quer cresceram muito a produção e o número de estabelecimentos, enquanto a têxtil cresceu em primeiro momento e depois reduziu o número de estabelecimentos. Em função de um crescimento mais acelerado de outros setores industriais, a têxtil perde participação do PIB industrial nacional.

O crescimento do setor possui um movimento de onda, com ascensão seguida de uma queda e novas ascensão. Um movimento cíclico que é descrito teoricamente por Schumpeter como algo normal dentro do sistema econômico. No período de 1998 a 2008, o número de estabelecimentos do setor têxtil cresceu cerca de 39,24\%, com uma expansão de $72,20 \%$ de 1998 até 2013, seguido de um declínio de $19,14 \%$ de 2013 para 2018. Esse movimento pode ser observado no gráfico 5 . 


\section{Gráfico 4 - Número de estabelecimentos do setor têxtil (2002-2018).}

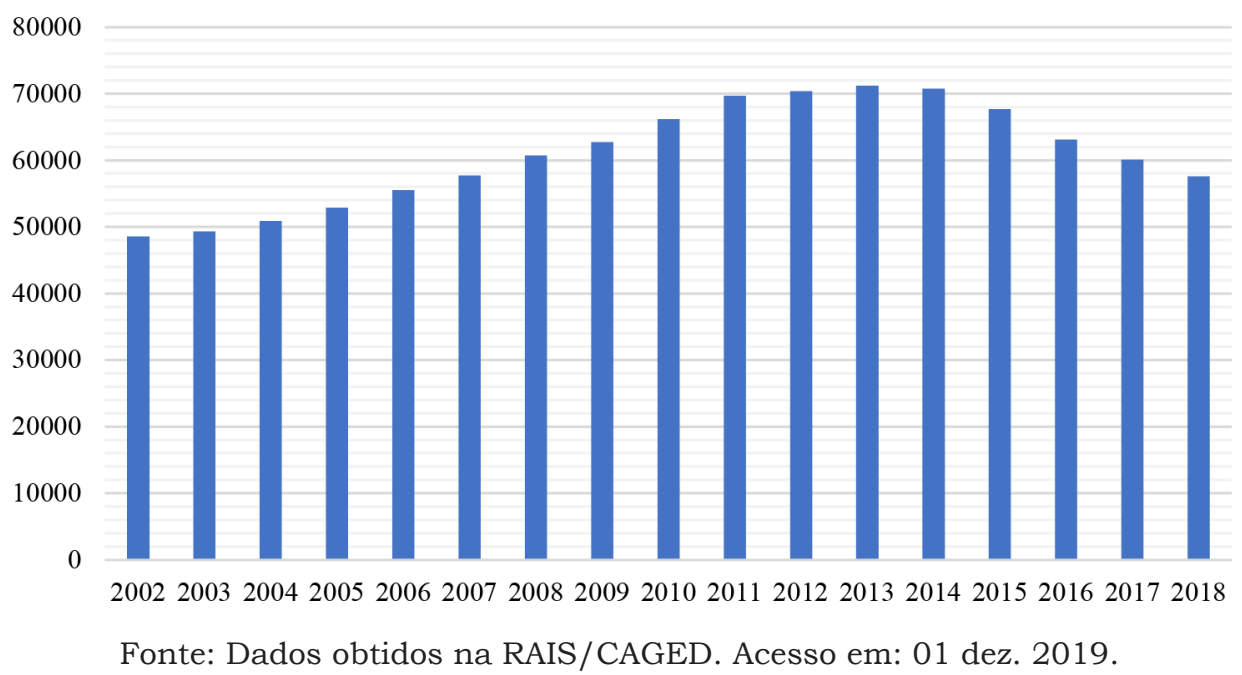

Segundo os dados da RAIS/CAGED, o declínio do número de estabelecimentos pós 2013 foi forte o suficiente para reduzir o número de empresas ao patamar do ano de 2007, que haviam 57.678 estabelecimentos em funcionamento. O número de estabelecimentos em funcionamento de 2018 foi de 57.575. Com o número de empresas reduzindo, a produção do setor tende a reduzir. Isso explica o crescimento decrescente a cada ano após 2010 exposto no gráfico 3. A produção individual das empresas aumentou, mas em contrapartida, o número de estabelecimentos reduziu, resultando nesse comportamento.

A indústria têxtil no Brasil apresenta heterogeneidade tecnológica bastante expressiva, com empresas atuando em padrão tecnológico de primeira geração, concorrendo igualitariamente com empresas de elevado desempenho mundial, mas também apresenta empresas modernizadas apenas em etapas estratégicas e um grande número de empresas com maquinário ultrapassado tecnologicamente (MELO et al., 2007).

O desenvolvimento tecnológico da indústria têxtil entrelaça outros segmentos como o agrícola (plantação de algodão), químico (criação de novas fibras) e metalmecânico. Dentre os avanços, a criação de novas fibras e máquinas conseguem ser mais rápidas. Segundo Melo (2007), o setor de fiação foi o que mais aumentou a produção a partir da utilização da tecnologia. 
A criação do sistema Open-End ${ }^{11}$ eliminou algumas etapas do processo de fiação, reduzindo drasticamente o tempo de produção, resultando no aumento expressivo da produtividade.

Levando em consideração os investimentos da indústria $4.0 \mathrm{em}$ Sewbots, nanotecnologia, impressão 3D etc., percebe-se que tudo poderá ser controlado por um computador central. Alves (2010) destaca os avanços tecnológicos da informática e da engenharia, reforçando que conforme a implantação dessas novas tecnologias, maior é o nível educacional exigido pela indústria, inclusive no chão de fábrica. Com a habilidade manual sendo substituída pelas máquinas, a habilidade intelectual passa a ser mais demandada (ALVES, 2010). Assim, a demanda por trabalhadores para chão de fábrica reduz, que geralmente são os trabalhadores com menos qualificação.

Como observado nos tópicos anteriores, ao longo da história do setor têxtil brasileiro, houve grandes investimento em máquinas, equipamentos e inovações. Em 2007, o setor era mais intensivo em capital que em mão-de-obra (MELO, 2007). Assim, os dados do gráfico 6, buscam ilustrar essa situação. Os dados apontam para uma redução do número de empregados no setor a partir de 2009.

Levando em consideração esses dados e também os apresentados nos gráficos 1 e 3, que mostram o aumento continuo da produção e das receitas, a indústria têxtil provavelmente ainda mantém o mesmo perfil, aquele descrito por Melo, um setor que possui maior intensidade de investimentos em capital (máquinas, equipamentos e inovações) do que em intensiva contratação de mão-de-obra. Embora outrora, o setor tenha sido grande empregador de mão de obra, mudando seu perfil de um setor intensivo em mão de obra para intensivo em capital.

11 O processo de fiação "open-end" elimina algumas fases do processo produtivo dos fios, como as da maçaroqueira e da conicaleira. Esse processo utiliza de rotores que giram em altas velocidades, retorcendo as fibras individualizadas, formando o fio. $\mathrm{O}$ sistema "open-end" produz três vezes mais rápido do que o sistema filatório convencional (KONDO et al, 1984). 


\section{Gráfico 5 - Variação do número de empregos no setor têxtil no Brasil de 2002 a $2018(2002=0,00 \%)$}

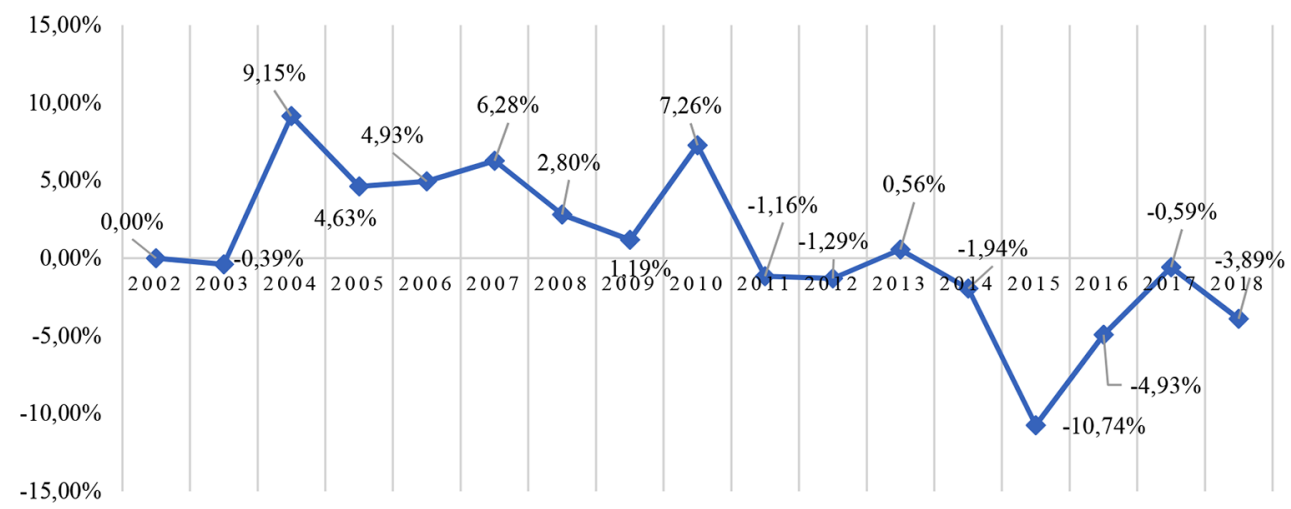

Fonte: Elaborado pelo autor. Dados obtidos na RAIS/CAGED. Acesso em: 20 nov. 2019.

Em média, o número de empregados da indústria têxtil aumentou 0,70\% ao ano, ao longo de 17 anos. O número veio crescendo positivamente entre 2002 e 2008. Entretanto, após 2008, houve uma queda do número de empregados, com destaque para o intervalo entre 2014 e 2015 , onde a queda ultrapassou $10 \%$, provavelmente em função da crise de 2008 e da crise que se iniciou no Brasil em 2014. No período de 2009 a 2018, houve uma redução de $1,55 \%$ ao ano do número de empregados do setor.

É necessário ressaltar que o desemprego no período de 2014 a 2018 pode não ter influenciado necessariamente em função do aprimoramento tecnológico na indústria têxtil. Como observado no gráfico 1 , o setor teve uma queda no faturamento de $5,43 \%$ de 2014 para 2015 e também reduziu $4,34 \%$ no mesmo intervalo.

Levando em consideração a crise citada por Barbosa-Filho (2017) que se iniciou em 2014, a queda das receitas em 2015 e 2016 pode ter sido afetada pela recessão econômica do país que atingiu não apenas o setor têxtil, como toda indústria. Conforme o gráfico 3, pode-se notar a queda da produtividade do setor e da indústria geral dos anos citados. Todavia, vale a ressalva de que, segundo Melo (2007), o setor é intensivo em capital, portanto, existe possibilidade que a crise não seja único fator explicativo para a queda do número de empregados. 
Outro fato a ser ressaltado nessa queda da empregabilidade, em 2014, é que a queda ocorreu com os trabalhadores com baixo nivel educacional. A tabela 2 mostra empiricamente essa variação negativa do número de trabalhadores com ensino médio completo ou menos qualificado a partir de 2014, enquanto o número de trabalhadores com ensino superior completo veio aumentando.

Tabela 2 - Série histórica: Grau de escolaridade dos trabalhadores do setor têxtil no Brasil (1998-2018)

\begin{tabular}{|c|c|c|c|c|c|c|c|c|c|c|}
\hline Ano & Analfabeto & $\begin{array}{c}\text { Até } \mathbf{5}^{\mathrm{a}} \\
\text { Incomp. }\end{array}$ & $\begin{array}{l}5^{\mathrm{a}} \\
\text { Comp. } \\
\text { Fund. }\end{array}$ & $\begin{array}{l}6^{a} \text { a } 9^{a} \\
\text { Fund. }\end{array}$ & $\begin{array}{l}\text { Fund. } \\
\text { Comp. }\end{array}$ & $\begin{array}{c}\text { Médio } \\
\text { Incomp. }\end{array}$ & $\begin{array}{l}\text { Médio } \\
\text { Comp. }\end{array}$ & $\begin{array}{l}\text { Superior } \\
\text { Incomp. }\end{array}$ & $\begin{array}{c}\text { Superior } \\
\text { Comp. }\end{array}$ & Total \\
\hline 1998 & 7.865 & 32.543 & 102.874 & 155.809 & 149.693 & 65.736 & 71.029 & 7.573 & 11.543 & 604.665 \\
\hline 1999 & 6.051 & 30.330 & 97.061 & 159.570 & 165.785 & 76.210 & 87.074 & 8.026 & 11.376 & 641483 \\
\hline 2000 & 6.019 & 30.744 & 95.377 & 165.171 & 186.632 & 89.497 & 108.123 & 8.711 & 11.820 & 702.094 \\
\hline 2001 & 4.759 & 27.400 & 87.602 & 156.093 & 191.079 & 93.209 & 122.670 & 9.663 & 12276 & 704.751 \\
\hline 2002 & 4.393 & 25.518 & 82.785 & 152.385 & 197.707 & 100.978 & 145.471 & 10.784 & 12.538 & 732.559 \\
\hline 2003 & 3.019 & 22.919 & 73.545 & 141.549 & 195.652 & 102.927 & 164.533 & 11.324 & 14.229 & 729.697 \\
\hline 2004 & 2.915 & 22.157 & 72.756 & 145.191 & 209.645 & 115.828 & 200.767 & 12.892 & 14.331 & 796.482 \\
\hline 2005 & 2.791 & 21.156 & 67.550 & 139.997 & 212.730 & 122.021 & 236.762 & 14.128 & 16.230 & 833.365 \\
\hline 2006 & 2.679 & 20.796 & 64.787 & 136.169 & 215.333 & 128.140 & 273.239 & 15.517 & 17.828 & 874.488 \\
\hline 2007 & 2.767 & 21.068 & 61.409 & 133.274 & 219.822 & 135.895 & 317.285 & 17.642 & 20.225 & 929.387 \\
\hline 2008 & 2.719 & 20.282 & 56.958 & 127.070 & 215.849 & 139.354 & 352.471 & 18.767 & 21.938 & 955.408 \\
\hline 2009 & 2.447 & 20.096 & 52.736 & 118.402 & 208.042 & 137.990 & 383.824 & 19.603 & 23.624 & 966.764 \\
\hline 2010 & 2.642 & 21.268 & 50.165 & 118.607 & 209.611 & 146.327 & 440.044 & 20.952 & 27.333 & 1.036 .949 \\
\hline 2011 & 2.469 & 21.696 & 45.612 & 109.263 & 197.675 & 142.700 & 454.410 & 21.345 & 29.790 & 1.024 .960 \\
\hline 2012 & 2.269 & 20.597 & 41.776 & 101.728 & 185.840 & 136.955 & 469.929 & 21.014 & 31.606 & 1.011 .714 \\
\hline 2013 & 2.193 & 20.339 & 38.975 & 96.965 & 177.143 & 134.815 & 489.515 & 21.590 & 35.894 & 1.017 .429 \\
\hline 2014 & 2.110 & 22.509 & 37.688 & 87.232 & 162.258 & 128.899 & 497.254 & 21.802 & 37.925 & 997.677 \\
\hline 2015 & 1.880 & 19.336 & 31.503 & 74.218 & 137.928 & 109.179 & 458.053 & 20.381 & 38.000 & 890.478 \\
\hline 2016 & 1.621 & 17.729 & 27.918 & 67.332 & 126.241 & 99.425 & 447.813 & 19.824 & 38.663 & 846.566 \\
\hline 2017 & 1.614 & 17.081 & 25.242 & 63.608 & 118.700 & 95.302 & 459.710 & 19.997 & 40.351 & 841.605 \\
\hline 2018 & 1.586 & 16.933 & 22.257 & 58.197 & 104.565 & 89.049 & 453.002 & 20.405 & 42.868 & 808.862 \\
\hline
\end{tabular}

Fonte: Dados obtidos na RAIS/CAGED. Acesso em: 16 nov. 2019.

As colunas em destaque mostram que aqueles que possuem maior grau de escolaridade estão sendo empregados no segmento. Em 2015 por exemplo, o número de empregados com ensino superior completo elevou-se, enquanto todos os demais diminuíram, principalmente os que não possuem ensino médio completo.

Mesmo com a queda dos trabalhadores com menor grau de escolaridade, percebe-se que aqueles que possuem o ensino superior completo somam apenas 5,29\% dentro total apresentado. Em 2010, essa proporção era de 2,64\%, em 2005 era 1,95\% e 1,68\% em 2000. A maior proporção de trabalhadores do setor possui ensino médio completo, em 2006 a escolaridade nesse nível representava 31,3\% e 56\% em 2018. Mesmo sendo o ensino médio completo a realidade da escolaridade da maioria dos traba- 
lhadores, nota-se um aumento de empregados capacitados dentro setor, indicando que a cada período, o setor demanda mão-de-obra cada vez mais capacitada.

Outro fator relevante para a discussão, é a redução do número de empregados com menos qualificação e o aumento do número de empregados com ensino superior completo. Para competir e conseguir maiores lucros, as empresas inovam. Com as inovações, o mercado demanda pessoas com mais qualificação educacional, assim como Schumpeter afirmava. Em função da aquisição dos novos equipamentos, mais atualizados tecnologicamente, nos diversos segmentos produtivos, a indústria têxtil passou a demandar uma mão de obra mais qualificada (MELO et al. 2007).

Assim, não se pode afirmar que o setor têxtil no Brasil realmente sofre com o desemprego tecnológico, mas não se pode retirar essa hipótese. Ele é intensivo em capital, mas sofreu um atraso tecnológico no final do século XX. Após a retomada do crescimento mundial após o ano 2000 impulsionado principalmente pela China, o setor volta a investir e inovar fortemente. As indústrias do setor começaram a investir em equipamentos tecnológico de novas gerações, fazendo com que alguns desses estabelecimentos resistissem as crises de 2008 e 2014, contudo, demandando trabalhadores cada vez mais capacitados. Ainda é incipiente a aplicação de tecnologias da indústria 4.0 no setor têxtil brasileiro.

Algumas considerações podem ser realizadas, como por exemplo o desemprego tecnológico acontece com quem tem menos capacitação profissional. Portanto, um mecanismo para minimizar esse problema gerado a partir do progresso tecnológico seria um intensivo investimento em educação. Dessa forma, o sistema econômico continua expandindo e aproveitando os benefícios do progresso, sem afetar negativamente os trabalhadores e a população de precisa da renda para viver.

\section{Considerações Finais}

Discutir sobre o desemprego tecnológico nos remete à importância da inovação tecnológica e do progresso técnico para o crescimento econômico, 
sendo entendida como importante variável estratégica para o setor privado como forma de obter ganhos de mercado e para o Estado, como mecanismo necessário para o desenvolvimento de um país.

O progresso técnico e a inovação tecnológica são muito relevantes para o crescimento econômico, mas eles geram desemprego, mesmo que momentâneo ou não. Nota-se que conforme os processos produtivos se tornam mais autônomos, maior é a redução do número de empregados com menos capacitação. Deste modo, o treinamento, a capacitação, a educação, torna-se um mecanismo para reduzir o efeito da substituição do homem pela máquina.

Como a indústria têxtil é o primeiro setor a se industrializar na $1^{\circ}$ Revolução Industrial, vivendo e aplicando todas as experiências das revoluções industriais subsequentes, buscou-se investigar esse desemprego tecnológico nesse ramo.

A partir do presente estudo, conclui-se que conforme for surgindo novas técnicas, ferramentas, modos diferentes de produção, máquinas mais produtivas, menos trabalhadores são necessários para que a produção cresça. Portanto, o trabalho humano é passível de substituição no que se refere a indústria têxtil.

Uma hipótese bastante debatida sobre o tema e que é de grande relevância, é que o desemprego tecnológico pode ser reduzido com a melhoria na educação. Como foi apresentado, a redução do número de empregados ocorreu principalmente naquele extrato de trabalhadores com menos qualificação, enquanto aqueles com ensino superior completo permaneceram empregados. Com esse novo paradigma industrial, o desemprego tecnológico é intensificado, sendo necessário uma melhor qualificação da população como mecanismo redutor desse fenômeno. Conforme o setor passou a adquiri novos equipamentos, com maiores níveis tecnológicos, em diversas etapas da cadeia produtiva, a indústria têxtil passa a demandar uma mão de obra mais qualificada para operar, manusear, melhorar essas máquinas e até em função do aumento de subsetores.

Conclui-se que não se pode demonizar a inovação e o progresso técnico, pois ele não permite apenas o aumento da produção, o que reflete 
em preços mais estáveis ou menores, bem como atua na permanência de indústrias no mercado em períodos de crises. Como a tecnologia desemprega principalmente os que tem menos capacitação técnica, uma possivel solução para solucionar esse problema seria justamente aumento os investimentos em educação, com um ensino básico sólido e o ensino técnico/ superior amplo.

Considera-se que a discussão proporcionada nesse artigo contribui para o debate e a reflexão acerca da importância da tecnologia e da educação, variável chave para a redução do desemprego.

\section{Referências}

ALVES, P. L. Reestruturação produtiva e os trabalhadores: um olhar atual sobre o setor têxtil em Sergipe. 123f, 2010. [Dissertação de mestrado] Pós-graduação em Desenvolvimento Regionais e Gestão de Empreendimentos Locais, Universidade Federal de Sergipe, Sergipe.

BACKES, D. S. et al. Internacionalização como desafio ao impacto da globalização: contribuições da enfermagem. Rev. Esc. Enferm. USP, São Paulo, v.48, n.5, p.772-777, out. 2014.

BARBOSA FILHO, F. H. A crise econômica de 2014/2017. Revista Estud. $A v$., São Paulo, v. 31, n. 89, p. 51-60, 2017.

BAYNE, E. History of the cotton manufacture in Great Britain. London, H. Fisher, R. Fisher, and P. Jackson. University of California Libraries, 1835.

BRUNO, F. S. A quarta revolução industrial do setor têxtil e de confecção: a visão de futuro para 2030. São Paulo: Estação das Letras e Cores, 2016.

CAVALCANTE, Z. V.; SILVA, M. L. S. da. A importância da Revolução Industrial no mundo da Tecnologia. In: ENCONTRO INTERNACIONAL DE PRODUÇÃO CIENTÍFICA, 7. 2011. Maringá. Anais eletrônico. Maringá. 2011. Disponivel em: <https://www.unicesumar.edu.br/epcc-2011/wpcontent/uploads/sites/86/2016/07/zedequias_vieira_cavalcante2.pdf>. Acesso em: 9 abr. 2019. 
CONCEIÇÃO, C. S.; FARIA, L. A. Padrões históricos da mudança tecnológica e ondas longas do desenvolvimento capitalista. In: DATHEIN, R., Org. Desenvolvimentismo: o conceito, as bases teóricas e as políticas [online]. Porto Alegre: Editora da UFRGS, 2003.

COSTA, S.; BERMAN, D.; HABIB, R. L. 150 anos da indústria têxtil brasileira. Rio de Janeiro: SenaiCetiqt/Texto\&Arte, 2000.

DAlmaso, S. A. R.; COUTINHO, M. C. Rev. Arq. Bras. Psicol. [online]. Vol.62, n.3, p.93-105, 2010.

DATHEIN, R. Inovação e Revoluções Industriais: uma apresentação das mudanças tecnológicas determinantes nos séculos XVIII e XIX. Publicações DECON Textos Didáticos, fevereiro de 2003. DECON/UFRGS, Porto Alegre, 2003.

DATHEIN, R. Teoria neoschumpeteriana e desenvolvimento econômico. In: Desenvolvimentismo: o conceito, as bases teóricas e as políticas [online]. Porto Alegre: Editora da UFRGS, 2003. Estudos e pesquisas IEPE series, p.193-222, 2003.

FREEMAN, C.; SOETE, L. A economia da inovação industrial. Campinas: Editora da Unicamp, 2008.

FUJITA, R. M. L.; JORENTE, M. J.: A indústria têxtil no Brasil: uma perspectiva histórica e cultural. Revista Moda Palavra e-Periódico, vol.8, n.15, 2015.

GORENDER, J.: Globalização, tecnologia e relações de trabalho. Rev. Estudos Avançados, 11(39), p. 311-361, 1997.

KON, A.; COAN, D. C.: Transformações da indústria têxtil brasileira: a transição para a modernização. Revista de Economia Mackenzie, São Paulo, n.3, p.11-34, 2005.

KONDO, J. I. et al. Qualidade do fio "open-end" obtido com matérias-primas produzidas por variedades paulistas de algodoeiro e suas misturas com poliéster. Bragantia, Campinas-SP, 1984. 
LAURITINO, T. K. S.; LAURITINO, T. N. S.; BOEMO, A. P. S. I. Indústria 4.0 no setor têxtil e de confecção. VIII Congresso Brasileiro de Engenharia de Produção. Ponta Grossa - PR, dezembro de 2018.

MAIA, et al. A cadeia produtiva da indústria têxtil e sua capacidade de induzir o desenvolvimento regional: o caso das indústrias do Norte de Minas. Fundação de Amparo à Pesquisa de Minas Gerais - FAPEMIG, UNIMONTES. Montes Claros, 2006.

MARINGONI, G. A superação dos obstáculos para a industrialização. IPEA Desafios ao desenvolvimento, Ano.9, Ed.74, 2012. Disponível em: <http:// desafios.ipea.gov.br/index.php?option $=$ com_content\&view $=$ article\&i$\mathrm{d}=2827$ : catid=28\&Itemid=23>. Acesso em: 16 set. 2019 .

MARX, K. (1867). O capital: Crítica da econômica política. 2. ed. São Paulo. Boitempo, 2014.

MATTOSO, J.: Tecnologia e emprego: uma relação conflituosa. Rev. São Paulo Perspec., São Paulo - SP, v.14, n.3, p.115-123, jul. 2000.

MEDEIROS, S. M.; ROCHA, S. M. M. Considerações sobre a terceira revolução industrial e a força de trabalho em saúde em Natal. Rev. Ciênc. Saúde Coletiva, Rio de Janeiro, v.9, n.2, p.399-409, jun. 2004.

MELO, M. O. B. C. et al. Inovações tecnológicas na cadeia produtiva têxtil: análise e estudo de caso em indústria no nordeste do brasil. Revista Produção Online, v.7, n.2, Ago, 2007.

NEIRA, L. G. Design, educação, cultura: origens do projeto têxtil no Brasil. Revista Brasileira de História da Ciência, v.6, n.1, p.78-88, Rio de Janeiro, 2013.

O SETOR TÊXTIL E DE CONFECÇÃO E OS DESAFIOS DA SUSTENTABILIDADE. Confederação Nacional da Indústria, Associação Brasileira da Indústria Têxtil e de Confecção - Brasília: Confederação Nacional da Indústria, 2017.

POCHMANN, M. Capitalismo e desenvolvimento. In: Brasil sem industrialização: a herança renunciada [online]. Ponta Grossa: Editora UEPG, 2016, p. $16-64$. 
RIBEIRO, A. F. Taylorismo, fordismo e Toyotismo. Rev. Lutas Sociais, São Paulo, vol.19 n.35, p.65-79, jul./dez. 2015.

RICARDO, D. (1817). Princípios de economia, politica e tributação. São Paulo - SP: Nova Cultural, 1996.

SAKURAI, R.; ZUCHI, J. D. As revoluções industriais até a indústria 4.0. Revista Interface Tecnológica, v.15, n.2, SP, 2018.

SCHUMPETER, J. A. (1942). Capitalismo, socialismo e democracia. Rio de Janeiro - RJ: Fundo de Cultura, 1961.

SCHUMPETER, J. A. (1911). Teoria do desenvolvimento econômico: Uma investigação sobre os lucros, capital, crédito, juro e o ciclo econômico. São Paulo - SP: Nova Cultural, 1997.

SMITH, A. (1776). A riqueza das nações: Investigação sobre a sua natureza e causas (Vol. 1). São Paulo - SP: Nova Cultural, 1996.

SINGER, P.: Globalização e desemprego. Contexto, São Paulo, 1999.

STEIN, Stanley J. Origens e evolução da indústria têxtil no Brasil 1850/1950. Rio de Janeiro: Editora Campus LTDA, 1979.

PORTAL DA INDÚSTRIA. SENAI CETIQT inaugura primeira fábrica modelo de confecção 4.0 do Brasil. 2018. <Disponivel em: https://noticias.portaldaindustria.com.br/noticias/competitividade/senai-cetiqt-inaugura-primeira-fabrica-modelo-de-confeccao-40-do-brasil/>. Acesso em: 16 set. 2019. 